\title{
fictocritical empathy and the work of mourning HEATHER KERR
}

\section{— Ethics/aesthetics And the dialectic of empathy}

Fictocritical effects in the service of ethically self-conscious cross-cultural writing belong to the larger category of 'trauma studies', conducted under the sign of the anti-aesthetic. ${ }^{1}$ Such a project proceeds as if ethics and aesthetics are not or need not be estranged from one another. This is evident in aesthetic practices that aim to 'heal' through cross-cultural reconciliation, often figured in imaginative acts of empathy/sympathy. Gail Jones has asked:

Where, in our theorising, is the space of the elegiac? ... The spaces of political bravery. Of risk. Of loss. Post-colonial studies is a melancholy field, concerned as it is with the elucidation of barbarity. Perhaps, therefore it needs access to a language (a tone, a poetics) to express the ethical imperatives of mourning. ${ }^{2}$

What is at stake in this fictocritical aesthetic remediation? What existing practices would it re-function, supplement or supersede? Is mourning adequate to the task of crosscultural reconciliation? How might fictocritical effects be animated in the service of this aim? In the process of exploring these questions I will suggest that the methodology of mourning is an allegorical vehicle for cross-cultural writing. Employed to remediate the colonial inheritance, it nonetheless requires acts of empathy according to models of the imagination that are part and parcel of that inheritance.

To explore such conjunctions of ethics and aesthetics in the context of Australian fictocritical writing is to confront the rejection of 'empathy' as a necessary and 
sufficiently 'radical aesthetic'. In her only reference to empathy in The Radical Aesthetic, Isobel Armstrong states that:

[t] his linked visual and spatial accommodation is important, for a freeing up of space for others has a double political and territorial and imaginative movement that has consequences for civil society ... Empathy is essentially a power-ridden construction of relations and a sentimental understanding of 'community'. It is an individualist reading of what must belong to a collective experience. 3

Perhaps the charge of individualism is to some extent inevitable if fictocritical writers are committed to proceed 'case by case', an 'I' and a 'thou'. ${ }^{4}$ Armstrong's understanding of 'empathy' invokes categories evident in Australian cross-cultural fictocritical writing (for example, space, movement, imagination). Also evident is a positive valence given to what might be called the sentimental imagination. My broad question is: can Australian crosscultural fictocritical writing re-function the sentimental tradition as a counter-discursive and radical aesthetic?

The aim is not to diagnose the presence or absence of sentimentality so much as to deploy sentimentality as a diagnostic tool. In pursuing these categories into fictocritical writing in the cross-cultural field it will be evident that the modernist disparagement of 'sentiment' and the Kantian rupture between thought and feeling have been replaced by a concept of 'sentiment', which values these categories' involvement in one another. Crosscultural remedial methodology relies on the re-aestheticising of the ethical domain. Instead of defining the aesthetic as a separate order of significance distinct from the cognitive and ethical spheres, the ethical and the aesthetic emerge in this work of reconciliation as a revived eighteenth-century conjunction. Anthony Ashley Cooper, Earl of Shaftesbury, for example, regarded the ethical and the aesthetic as exercises of the same (imaginative) faculty. 5 Joseph Addison and Richard Steele affirmed the sentimental imagination's responsiveness to the suffering and distress of others: 'sentiment ... originally meant not simply feeling, but feeling justified by a moral idea'. Postcolonial cross-cultural writing, understood as an example of a 'modern ideological passion', is a 'true avatar of moral sentimentalism'. ${ }^{6}$

In this sense, the 'affective', 'ethical' and 'aesthetic' turns repeatedly diagnosed in contemporary culture belong together as instances of the post-romantic inheritance of the sentimental tradition. In attempting to make the affective (feeling) perform the work of the ethical (thought) through a species of identification, contemporary cultural analysis at the same time tries to keep the distinction between thought and feeling in place, thus re-enacting the central problem of sentiment. We inherit these concepts as side by side yet distinguished from each other, 'neighbouring' in their 'separation'.7 Even now the 
asserted conduction between them is achieved through the deployment of abstract terms such as 'motion' or 'movement', along with other words that describe the work of the imagination familiar in eighteenth- and nineteenth-century thought. 8 The 'sympathetic' and 'ethical' imaginations are characteristically 'active' in this oscillation between thought and feeling, an aesthetic effect that requires the aesthetic order to be distinguished but not separated from the ethical. 9 In the hermeneutics of sympathy implied by elegiac historiography the poetics of elegy would move the reader to 'respond with a concomitant emotion and imagination ... to answer the [writer's] call', a dynamic in which it is implied that writer and reader contribute equally.10 In a thus renovated postcolonial field the work of sympathy nonetheless 'takes place within the realm of fiction, mimesis, representation, and reproduction ... our experience of sympathy depends on an aesthetic experience. Sympathy in this sense is always already an aesthetic experience.'11

Jones's speculation that an aestheticised ethics might remediate the theoreticism of postcolonial studies seems to imply that empathic responsiveness to suffering (past and present) would activate mourning as a methodology. Before mapping the concepts of melancholy and mourning, I want to explore briefly some possible models of empathy/ sympathy that might prove adequate to this culturally therapeutic task. I will suggest that the dialectical interplay of ethics and aesthetics, thought and feeling, sketched above is replicated in the conceptualising of empathy. Further, I will suggest that the same conceptualisation describes the processes of melancholy and mourning. As a methodology then, postcolonial empathic fictocriticism might be expected to repeat the dialectical interplay of ethics and aesthetics inherited from the sentimental tradition. In particular, I will argue that fictocritical effects in the field of postcolonial studies redeploy eighteenth- and nineteenth-century models, although the currently dominant terms (empathy and ethics) usually replace an earlier vocabulary of 'sympathy' and 'morals'.12

What Armstrong calls the linked visual and spatial model of empathic accommodation, a double territorial and imaginative movement, hints at the key issue for Thomas McCarthy in models of empathy: 'the way in which the self participates intellectually and emotionally in the experience of the Other'. ${ }^{13}$ In the eighteenth and nineteenth centuries 'sympathy' is a particular idea of the imagination and a central moral and aesthetic problem. The sympathetic imagination 'is able to penetrate the barrier which puts space between it and its object' and 'secure a momentary but complete identification with it'. ${ }^{14}$ As a simultaneously intellectual and emotional activity, this momentary, paradoxical selftranscendence and self-involvement is often described in metaphors of movement. James Engell summarises the early nineteenth-century complex of activities associated with romantic sympathy: the ability to 'escape' the self, to 'identify with other people', to 'perceive things in a new way' and to 'coalesce' subject and object.15 According to 
McCarthy, romantic 'Absorption in the Other ... demands a great degree of self-consciousness, an ostensibly paradoxical dialectic which illustrates sympathy's roots in moral as well as aesthetic theory'. 16 The problems that accompany this dialectic remain pressing and are reflected in Armstrong's understanding of empathy as power-ridden and individualist. Does sympathy/empathy, as McCarthy argues, require a 'blurring of self and Other'; how is the self involved with and differentiated from the other? 'Does self-awareness follow from Other-awareness; to what extent is the focus in sympathy on the self versus the Other?' In this dialectical model of sympathy/empathy, thought and feeling produce a 'shared experiential space between the sympathetic self and the Other'.17

McCarthy's summary of recent psychological models under the heading 'empathy and cognition' lists four phases of empathy that might be regarded in part as the contemporary afterlife of eighteenth- and nineteenth-century sentimentalism. First, an involuntary identification, in which 'we are projected into the other person by our own fantasy, response, or feeling'. Second, 'incorporation', or 'taking the other person into ourselves'. Third, 'the dialectic between the actual me and the me which is identified with the other person', and fourth, 'detachment', or deliberately moving away 'to gain the social and psychic distance necessary for objective analysis'. The effects of 'absorption and blurring of identities', characteristically described as motion or reverberation, 'imply a back-and-forth movement and suggest that empathy is a process', not a moment.18 Empathy works the gap between self and other and repeats the dialectical oscillation between sameness and difference, thought and feeling, ethics and aesthetics inherited from a non-Kantian tradition of moral philosophy.

Gail Jones provides a striking visual equivalent of empathy as an active process, "based on the necessity to reconcile the presumed separation between self and other', 19 in her fictocritical essay 'Thaumatropes':

I possess a small antiquarian scientific toy called, somewhat ostentatiously, a thaumatrope. Despite its name it is blithely simple, consisting of a series of cardboard discs strung on a string. When the discs are rotated, by breath or manipulation, images on either side are visually combined. On one side ... is a black Mammy figure, on the other a white baby; when the disc spins around the woman appears to hold the baby. (This is an especially captivating image for me because it recapitulates a childhood dream in which I believed myself the daughter of an Aboriginal mother.)20

The oscillation between objectification, a 'looking at the Other', and a 'blurring of identities' that enacts the 'fantasy' of 'incorporation' is followed by the 'dialectic between the actual me' of the self-conscious narrator and 'me' identified with the 'other person'. Jones's self-reflexive writing also stages the final 'detachment' and 'objective analysis' in 
which the space between self and other opens again. The vigorous movement of the thaumatrope produces a model for a briefly shared intersubjective space, an empathic reconciliation. The empathic process is like a 'bold swinging-demanding the most intensive stirring of one's being into the life of the other', physical metaphors that recall the late-eighteenth-century ideas of self-transcendence. ${ }^{21}$ The thaumatrope is an object to think with, literalising the movement, identification, fantastic projection, incorporation, self-conscious oscillation between subject positions, and analytic detachment that characterise the sentimental imagination in its empathic mode.

Jones allegorises the thaumatrope's pre-cinematic montage as 'a kind of metaphor for cross-cultural scholarship'- 'hoping to set in process a dialectic by which ... the self and other will breezily combine, cultures discontinuous will appear continuous', all the time knowing this is an 'anterior misrepresentation'. Jones acknowledges a need to honour 'the exquisite, grave and finally humane banality of affect itself', using the thaumatrope to perform her desire: 'the impelling exhalation, the fast-motioning embrace of that which wishes to reconvene, ideally and utopianly, the beautiful black woman with the small white baby'.22 The dialectic enacted by the thaumatrope produces a series of intersubjective relays that characterise empathy as a linked visual and spatial effect, in particular the simultaneous availability of multiple viewpoints. Recent scholarship, surveyed by Thompson, suggests that empathy 'provides a viewpoint in which one's centre of orientation becomes one among others', ideally without hierarchy. 23

The same dialectic of self and other, neighbouring and separation, has been offered as the condition of possibility for an ethical politics of text and commentary. In the face of a need for what they call a 'more self-conscious mode of textual commentary', Bob Hodge and Alec McHoul suggest that fictocriticism might model a practice 'where the term "commentary" itself might now be under erasure'. 24 Their model includes the political, territorial and imaginative movement that empathic criticism requires in order to free up a space for others.

Of course this would mean risking falling into the well-defined spaces of mastery and libertarianism. Those grooves would always be beckoning to either side of the space or spacing between them. But it remains the case that any such pair of grooves (if they are in any way distinct, and we think they are) must as it were, throw up a ridge between them. It is this ridge that we would be wanting to negotiate (almost in the topographical sense). 25

Fictocriticism might produce an empathic critical stance, a shared textual horizon somewhere in the spaces produced by what Heidegger calls 'the struggle' between a critical practice that 'leaps in and dominates' and another that 'leaps forth and liberates'. 26 
Jones has reservations about the thaumatrope's usefulness as a model of a more selfconscious mode of cross-cultural scholarship. Perhaps the 'blurring of identities' that constitutes one phase of the empathic process would dominate in montage's 'fastmotioning embrace'. Perhaps the thaumatrope's poetic effect is too like early nineteenthcentury models of hermeneutics. William Hazlitt's essay 'On Reason and Imagination' provides an example of the nineteenth-century model of interaction between text and reader:

Wherever any object takes such a hold of the mind as to make us dwell upon it, and brood over it, melting the heart in tenderness, or kindling it to a sentiment of enthusiasm;- -wherever a movement of imagination or passion is impressed on the mind, by which it seeks to prolong and repeat the emotion, to bring all other objects into accord with it, and to give the same movement of harmony ... to the sounds that express it-this is poetry. 27

Jones knows that in her speculation on an empathic tone or poetics to express affect there is an echo of this and other inherited poetic and critical traditions: 'A Romantic in spite of myself'.28

She is not alone in apparently rejecting the romantic hermeneutics of sympathy as a model for the politics of cross-cultural scholarship. In No Road (bitumen all the way) Stephen Muecke suggests that instead of the blurring of identities that characterise a romantic aesthetic based on metaphor, 'you stand your text beside the text of the other so there is a parallelism, perhaps only accidental encounters, like we produced in Reading the Country':

These two-figures—circle and parallel—represent a confrontation of methodology between, on the one hand, the romantic aesthetic of participant ethnography, in which the subject and object merge phenomenologically, and, on the other, the desire to retain cultural autonomy and difference-the parallelism of both subject and object.29

Hodge and McHoul regarded Reading the Country as exemplary of a fictocritical ethic of text and commentary. In Muecke's model, a figure for metaphoric 'blurring' (montage) is replaced by a figure for analogical contiguity (collage). Rather than seeing this as radically different from Jones's model, I would suggest that the focus has shifted from 'merging' to the self-conscious 'detachment' that re-opens the space between self and other. Both these figures for empathic cross-cultural scholarship derive from the same model of a dynamic imaginative process developed in the sentimental tradition. Read together they rehearse the defining elements of the sentimental dialectic: 'blurring' and 'detachment'. Neither is without its dangers (of obliterating difference, of reification of 
the other, for example). However, the ambition of both these fictocritical effects is to reconvene, perhaps only ideally and utopianly, feeling and thought, aesthetics and ethics, refunctioning the dialectical movement between 'neighbouring' and 'separation' that characterised non-Kantian sentimentalism.

\section{- Collage: Sentimental allegory}

The compositional pair collage/montage cannot be deployed without a contaminating affect. Indeed, allegoricism and sadness are functions of each other, according to postKantian models of the aesthetic. 30 To work with fragments is to engage in a potentially melancholy production of allegoresis, a re-coding of de-contextualised bits and pieces. ${ }^{31}$ For Walter Benjamin this 'pile of ruins' is the mournful point of departure for the baroque 'allegorical sensibility' and, in Eric Santner's view, 'opens up extravagant and excessive possibilities of recollection, recombination, and interpretation. It is in this sense that the baroque allegorist has been regarded as the forebear of the postmodern bricoleur.'32 As Benjamin aphoristically put it, 'allegory is in the realm of thoughts what ruins are in the realm of things'. 33 According to Linda Nochlin, in modernity, 'fragmentariness' is a 'quality shared by the perceiver-constructor and the object of construction'.34 (What fragmentariness was to modernism, hybridity is to postcolonialism, perhaps.) Peter Burger characterises 'allegory which is fragment' as the correlative of 'history as decline': two responses to such historiography are utopianism and nostalgia. 35

This work on the conjunction between typographic display and elegiac tone began with the decision to explore the politics that attends the fictocritical effect of textual collage/montage, 'writ[ing] with the discourse of others'. 36 The reification of 'voice' as textual fragment that typifies the architectonics of bricolage might now be partnered by the attentiveness to affect implicit in listening for 'tone': 'there is no escaping the crying of the ghosts ... one needs to be able to bear listening to the ghosts'. 37 Self-conscious efforts at 'speaking montage' are allegories of knowledge. In his essay on 'Ethnographic Allegory', James Clifford notices 'a recent tendency to distinguish allegorical levels as specific "voices" within the text'.38 As Gregory Ulmer notes, cut and paste, collage/montage, this self-conscious writing with fragments and spaces is 'explicitly organized to say what it is doing' and 'to provide its own commentary'.39 According to Clifford, we 'say of it not "this represents ... that" but rather, "this is a (morally charged) story about that"'.40

In fictocritical collage/montage, the blank space between text fragments is never neutral. It can point to contradictory but paired allegorical meanings, both as a nostalgic sign of rupture and lost totalities and as a signifier of utopian possibility. One effect is shared: the space on the page figures in visual allegory a space in which the imagination 
is understood to do its (various) work, in particular the imaginatively produced 'analogical' historical tie between selves and others. The space for an 'imaginative transfer' between a 'here' and a 'there' is visualised in Muecke's Textual Spaces, for example, where parallel columns of type display contiguous but discrete textualised horizons. ${ }^{41}$ The white space between is a third zone where the imagination plays the 'ridge' thrown up between antinomies. In Richard Kearney's view, the 'oscillating movement' required of the imagination creates the intersubjective space of ethical praxis.'The imagination ... needs to play ... in a way which animates and enlarges our response to the other'. 42 In effect, a rehearsal of the process of empathy both closes the gap between self and other and inevitably reopens it as a condition of historical difference. With regard to postcolonial thought, these visual aesthetics signal an urge to ethical engagement.

The 'play of voices' in collage/montage attempts the aestheticising of principled stances in relation to objects of knowledge. In the case of collage writing, the ethical effect of multiple stories/voices is visible in the typographic layout. The spaces between textual fragments attest to an alleged modest refusal to claim authority or to tell the other's story. Empathic attentiveness informs both the self-conscious production and reception of the fictocritical collage effect. Yet empathic criticism is not unproblematic.43 Gaye Tuchman cautions that "whether an ethnographer or historian is working for us or them, that person still faces the task of assemblage, of making a montage "that speaks" (whether or not the text is understood to be multi-vocal, "a text that speaks itself")'.44 Addressed primarily to the eye, the collage writing of the allegorist as bricoleur is symptomatic of a mutilated and incomplete archive of the past, and/or the incommensurability of competing 'stories' in the present. In Stephen Greenblatt's words, 'Allegory arises from the painful absence of that which it claims to recover'45 and the collagist works with a textual equivalent of the skull as the pathetic image for loss; she needs to be able to bear the hollowed out spaces. Jones's call for an elegiacs of postcolonial cross-cultural studies asks us to be affected by the effects of history: "Why did imperialists collect native skulls?'. ${ }^{4}$ She invites us to 'seek out the surfaces of new and difficult subjects', to imagine how 'we might chart the distance between those brute materialisations of political struggle ... and the historical dematerialisations by which the skulls of the vanquished become empty vessels'. 47

The aestheticised ethics of the compositional pair collage/montage are offered in the service of various mediations that make up historical and social ties. In this sense at least the linked visual and spatial accommodation of empathy frees up a space for others in a linguistic instance of a sentimental community without the sneer of disparagement that accompanies Armstrong's use of the term. Fictocriticism relies on a politicised 
sentimental imagination that aims to enhance our capacity to be affected by the effects of history. In order to develop this idea further I want to revisit the example of Stephen Muecke's fictocritical writing, especially Reading the Country: Introduction to Nomadology (1984), Textual Spaces: Aboriginality and Cultural Studies (1992) and No Road (bitumen all the way) (1997). Reading the Country avoids the effect of mastery (it doesn't 'speak for' Paddy Roe's dreaming), and avoids falling for the apparently doomed utopics of unmediated liberty (a text that impossibly 'speaks itself'). 48 In the Road to Botany Bay: An Essay in Spatial History, Paul Carter suggests that Reading the Country is an example of 'the device of the historian absenting himself as author':

Krim Benterrak, the artist in this book, records one country, Paddy Roe, a local aborigine ... narrates another, the theoretically informed Muecke constructs yet another; but the implication that by cutting them and overlaying them, we can attain the multidimensionality of an aboriginal narrative seems to me an editorial illusion'.49

Muecke's work can be read in terms of the desire 'to replace the uni-vocal linearity of conventional history with a "bricolage" of "texts". "It demonstrates clearly ... the authority of all viewpoints. But such an approach still perpetrates an illusion of its own; that, in some way, the multidimensional spatiality of aboriginal culture is hereby being imitated.'50 Paul Carter reads the 'bricolage of texts' as a cross-cultural hybrid writing. Fictocriticism as 'hybrid writing' produces the writer's own 'hybridity' as one of its effects, and could be understood as a species of ethnographic allegory.

In a sense, Carter wants Reading the Country to valorise more successfully its textual hybridity, inviting Muecke to perform an even more extravagant allegory than the modesty of 'parallelism' or analogical contiguity would afford. It could be argued that The Road to Botany Bay needs Reading the Country to perform its 'geometry' more efficiently because Muecke's borders, gaps and edges are the other to Carter's preferred 'haze which preceded clear outlines'. ${ }^{51}$ Ken Gelder and Jane Jacobs have remarked on Carter's 'nostalgia for an "original" moment', figured in the 'haze'.52 In the terms we have been deploying, Muecke is required to perform the political utopianism that is the other to Carter's alleged nostalgia. Read as responses to history as decline, the project of spatial history is no less allegorical than Muecke's collage.

Both projects aim to renovate critical writing on the contact zone through an investment in kinds of metaphor that solicit activities of the reader's empathic imagination. Carter puts it like this in The Lie of the Land:

To avoid compacting the ground ... we need to tread it lightly, circumspectly. The approach must be poetic rather than philosophical ... the challenge ... is to move differently, to learn to dissolve the emotionally catatonic and historically destructive 
opposition between mobility and stability ... But for this to happen, poiesis—all that is comprehended by the Western arts of representation-would need to undergo a renovation. 53

The analogical nature of the imaginative transfer that characterises empathy suggests that empathy itself works 'allegorically'. Pursuing the terms of the sentimental tradition within which I have placed the process of empathic transfer, it is possible to see the fictocritical effect of Carter's 'mobility' and the 'haze which preceded clear outlines' as equivalent to Jones's thaumatropical montage, the blurring of self/other distinctions that characterised the ecstatic and ex-centric phase of empathy. Jones's thaumatrope, with its provisional effect of the 'fast motioning embrace', and Carter's restless metaphoricity of (tactful) movement, visual haze and acoustic reverberations refunction the eighteenthand nineteenth-century conception of the sympathetic imagination as that which is 'able to penetrate the barrier that puts space between it and its object' and 'secure a momentary but complete identification with it'.54 Further, Carter's 'haze' belongs with Muecke's 'clear outlines': together they replay the dialectical oscillation between 'neighbouring' and 'separation', each figured though their equivalents in montage and collage, metaphor and analogy respectively. These examples suggest the fragmented and dispersed afterlife of a non-Kantian heritage available to cross-cultural scholarship. They offer glimpses of how the fragments of this tradition might be (provisionally, partially) reconvened, though it remains questionable to what extent such a renovation would constitute a 'radical aesthetic'.

\section{— Therapeutic melancholy and elegiac historiography}

The call for a poetics of mourning in cross-cultural scholarship is a somewhat belated gesture. 55 The discussion will suggest that the predominantly Freudian idea of melancholy as 'obstructed' mourning evident in certain studies of cultural trauma is a pathologising of the second phase of the empathic process described in eighteenth- and nineteenth-century sentimentalism. Empathic fictocritical effects in the service of crosscultural scholarship do not appear to regard the involvement of self and other as problematic. Instead, the compositional pairs from the previous discussion suggest a model in which provisional therapeutic effects might be understood to flow both from a so-called 'perverse' melancholy and a 'normal' work of mourning. 56

The Freudian tradition, according to Santner, equates the melancholy response to loss with secondary narcissism, and intensifies it as a pathology in which the otherness of the loved object is repressed; "narcissistic love plays itself out in the (non-)space where "I" and "you" are not perceived as having hard edges'. 'The melancholic grieves not so much for the loss of the other as for the fact of otherness and all that entails.' 57 'Normal' 
mourning opens up the space between 'I' and 'thou', 'here' and 'there', 'now' and 'then'.58 The condition of 'continuity' between self and other in 'perverse' melancholy must be given up for the 'contiguity' that characterises the 'normal' work of mourning. In Santner's formulation of the Freudian paradigm:

[t] he capacity to feel grief for others and guilt for the suffering one has directly or indirectly caused, depends on the capacity to experience empathy for the other as other. This capacity in turn depends on the successful working through of those primitive experiences of mourning which first consolidate the boundaries between self and other, thereby opening up a space for empathy. 59

Viewed through the tradition of sentimentalism that is perhaps a condition of possibility for these models, it appears that the psychoanalytic tradition has not only sundered two phases of a single process but also reversed the actions of the sympathetic imagination. In the Freudian schema, empathy is an effect of the 'space' of difference that must be opened up before empathy can occur. The 'blurring' of identities in the ex-centric imaginative movement that characterised a necessary first phase of the process is uncoupled from the differentiating 'detachment' that concluded the dialectic of empathy in the sentimental tradition. Severed from its partner, this (melancholy) component is then understood as a sickly 'loop' of self-involvement rather than an ecstatic movement of self-transcending incorporation with the other. The name and value of empathy is then given to the condition of contiguous separation, as though one part of the machinery of empathy must now stand in for the whole ensemble.

A prominent topos of cultural analysis is that of 'obstructed mourning', sometimes cast as melancholy stasis. For example, in the historiography of postwar Germany a 'melancholy dialectic' is understood to prevail.60 Similarly, in the historiography of early modern American captivity narratives, Mitchell Breitwieser detects a 'melancholy semiotic' as an effect of implicit injunctions against 'excessive mourning', a preference for typological or emblematic techniques of analysis and a tendency to remain fixated on a two-dimensional image of the beloved object, which is thus psychically 'encrypted'. ${ }^{61}$ These features are read as analogous to the Freudian model of melancholic 'failed mourning'. In place of stasis the historian of early modern cultural trauma must deploy a 'polymorphic mode of exegesis', 62 taking up multiple points of view from which to examine the relationship with the loved object. However, even this pluralising of horizons that keep opening up the space between 'I' and 'thou', 'here' and 'there', 'now' and 'then', might become merely mechanical if anxiety is not allowed to surface. This feeling must be relived if healthy mourning is to displace a so-called 'structural mourning' drained of affect. Structural mourning is understood as a defining symptom of 
the 'posts' (post-Holocaust, post-modernity) and in its pervasive manifestation in theoretical discourses is characterised by particular vocabularies.

The appeal, in these discourses, to notions of shattering, rupture, mutilation, fragmentation, to images of fissures, wounds, rifts, gaps, and abysses is familiar enough ... These discourses propose a kind of perpetual leave taking from fantasies of plenitude, purity, centrality, totality, unity, and mastery. 63

In a discursive construction that sees the decentred subject compelled to repeat the splitting that propelled him into the symbolic order, mourning is a condition of 'beingin-language'. ${ }^{64}$ This gives rise to 'an abstract mode of bereavement' that is the condition of all writing.

Returning to Jones's appeal to an expressive poetics that might reanimate theory with an elegiac tone, it becomes apparent that her targets are the 'rhetorics of mourning' embarrassed by appeals to actual human suffering. Rejecting the thaumatrope's unsatisfactorily melancholic elegiacs of repetitive 'typological' images, Jones turns to the empathic consideration of particular individuals. She works to preserve the difference between what Ricoeur calls the 'course of history and the course of things'.65 Her willingness to consider the resources of 'sheer pathos' for a politically engaged writing refuses to accept theoreticist disparagement of the 'banality of affect'. 66 Discourses devoted to the mechanics of structural mourning would regard the appeal to 'humane' affect 'as a sign of lack of rigour, nostalgia, sentimentality'.67 Examining aspects of the ethnography of grief, Jones considers her relationship to those others whose pain provides the occasion for commentary. Her self-conscious decision to set aside the typological model of cross-cultural scholarship can be read against the particularity of an essay written 'in memoriam'. In 'Skulls, Fontanelles, and the Spaces Between; in memoriam Fanny Balbuk' Jones makes the suggestion that 'there is a need to supplement rationalist and mimeticist explication, to veer and seek out the surfaces of new and difficult subjects. To veer, perhaps wildly, into realms of ... the intolerable elegiac'. 68 The strong metaphorics of movement, spatialising and ecstatic excess suggest a revised template for the other-involvement and self-forgetting that characterised the 'first phase' of empathy. Her proposed cultural therapeutics in the elegiac mode would require a combination of personal sensibility and ethical attention to particular instances. This kind of mourning would have to risk, in Armstrong's dismissive terms, recourse to the 'individualist' and 'sentimental', at the same time proposing affect as the unsettling ground for a 'collective experience'. 69

In conjunction with attention to the individual case, healthy mourning predicated on a 'polymorphic mode of exegesis' allegedly requires a continual and pain-filled reviewing 
of the evidence. A vocabulary of dynamic movement, strongly reminiscent of Paul Carter's model for a renovated poiesis, characterises this model: 'mourning demands perpetual motion, allows for no such [typological] fixities, provides neither certainty nor stasis'. The denigration of stasis in favour of a 'nomadic wandering' through the archive, 70 forever unsettling the orientation of self/other, here/there, now/then, is a familiar contemporary topos. In the postmodern critical heritage decentred subjectivities are urged to embrace the play of differences.

Postmodern critics invite readers to mourn the shattered fantasy of the (always already) lost organic society that has haunted the Western imagination and to learn to tolerate the complexities and instabilities of new social arrangements as well as more hybrid ... forms of personal, sexual, cultural, and political identity. It is a matter of learning to live as a nomad, as one who has learned that survival is a constant improvisation. ${ }^{71}$

Hybrid writing, nomadology and collage/montage effects all too readily slot into this rhetoric of structural mourning. Further, the accord between models of global, postmodern, nomadic and affectless structural mourning and the American, early modern 'wandering up and down' of 'grief in motion' might raise suspicions that mourning is not inevitably remedial in its role as a cultural analytic.

In 'Skulls, Fontanelles and the Spaces Between' Gail Jones nonetheless risks refunctioning the melancholy stasis represented by the 'skulls of the vanquished', imagining instead the resistant spatial stories mapped by the Indigenous woman's defiantly walking the colonial city. Imagining Balbuk's 'wandering up and down' as a work of mourning, Jones pays attention to a passionate journeying that at once produces 'the space of the elegiac' and 'political bravery'. 72 This attempt to imagine what fictocritical effects might be possible when writing with the 'feelings left out of the historical narrative' returns affect to postmodern nomadism, remediating a potentially structural mourning. ${ }^{73}$ For Walter Benjamin, the quintessential object of baroque allegory is the skull, empty, silent, appropriable. Jones takes the 'skulls of the vanquished', people reduced to the order of things, as a point of departure for a counterdiscursive move. The particularity of the elegiac gesture, 'in memoriam Fanny Balbuk', marks this as a work of mourning, refunctioning the stasis of melancholy skulls with the imaginative animation of Fanny Balbuk's movements. The melancholy field of postcolonial studies might, momentarily, resonate with the tone of a new elegiac historiography, honouring the 'simultaneous delectation and refusal of the experience of loss'.74 Balbuk's 'spatial stories' figure a methodology for inconsolable suffering, the 'acute state of mourning' that 'is the only way of perpetuating that love which we do not want to relinquish'. 75 Jones has to perform a double gesture, honouring the melancholy 
repetition compulsion of Balbuk's refusal to 'let go' of Indigenous cultural places and spaces, and modelling an elegiac historiography as a work of mourning that can preserve the order of history through the analogical tie of self and other.

What then of the 'extravagant' allegorical conjunction between collage effects and the 'intolerable elegiac' sketched so far? It takes a bit of effort to overcome the resistance of the materials in this act of temporary reconciliation, knowing that things are 'never [neatly] back to back'. 76 The suggestion that they are two sides of each other asserts a continuity between montage and elegy. This is rather different from the rupture implied by Jones's speculation that a wild veering in the direction of the elegiac would trace the surface of new (however difficult and resistant) problems. Might we find in contemporary versions of the impulse to ethically 'utopian' collage/montage, 'the spaces between' and allegories of discursive reconciliation, a simultaneous desire to turn away from, and an inability to leave behind, the melancholy devices of a failed modernism? In any case, fictocritical cross-cultural writing seems unwilling to pathologise the resources of melancholy. Read back through the sentimental tradition, melancholy and mourning belong together as elements available to an aestheticised ethics.

\section{- Elegy and fictocritical excess}

Fictocritical effects that oscillate between the compositional pair of (perverse) melancholy and (normal) mourning allow us to glimpse the architectonics of 'a project', in Nochlin's words, 'that includes love and suffering'. ${ }^{77}$ Such a project is evident in artist and writer Rod Moss's 'Elegy', written for members of two Aboriginal families. ${ }^{78}$ An attention to typography, mimicking the centred text of a gravestone, is combined with a tone that Jones might label 'sheer pathos'. 79 This combination strongly recalls the poetics of romantic epitaph and the valorising of fragmentariness but, in a potentially counterdiscursive move, the epitaphic aesthetic does not ventriloquise the voice of the other. In Moss's work the text/image combination is allegorical. The collage speaks of his cultural difference. 'Grief finds its focus' in a photograph that becomes the occasion for the writing. 'This non-Arrernte focus. This photo. These published solitary thoughts. Such documentation is anti-thetical to their letting go' .80 The potentially melancholy fixation on a static two-dimensional image is supplemented by an exorbitant, even embarrassing 'tone', here put into the service of a politically engaged writing.

The elegiac 'tone' is perhaps attractive to the white commentator who needs to mark out a principled stance off-centre, because it suggests the intensity of 'neighbouring' but keeps open the space of 'separation', or analytic detachment, characterising the final phase of the empathic process. Just as Jones's 'scientific toy' enacted the symbolic 
management of desire and loss in an uncanny refunctioning of Freud's paradigmatic 'fortda' game as mourning play, so Moss uses a photograph to dose out the homeopathic pain of mourning.

The photo stays in the bedroom. Pettrina and Christine Johnson are variously maternal about our infant girl whose whiteness and stiffness bequeath a hyper-reality of unbelonging ... Most urgent are the upturned, cupped hands of Christine ... It is, with hindsight of her imminent death at 23, a pleading to suckle that will go unfulfilled. And the intense, dry air fights her off, as, one feels, the child would do. Today, Pettrina remains childless ...81

Sadness and desire sit side by side. The white man's sadness is paired with the Aboriginal women's ostensible desire for the white baby. Just such a conduction back and forward between sadness and desire, separation and neighbouring, is allegorised in Gail Jones's 'Thaumatropes', an essay also partly concerned with writing about Aboriginal expressions of grief in the context of cinematic experience (the death of John Wayne, for example). 'To grieve for John Wayne is insubordinate; it is a reclaiming of social consequence from mere simulacra; it is a conversion of the specular into the performative'. 82 Moss uses the fragmentary form of the epitaph and the 'fort-da' effect of re-viewing the photograph to reclaim the social consequence of mere simulacra, oscillating between the specular and performative. As a recapitulation of the model of empathy to which I have been referring, Moss's 'Elegy' maps the phases that are familiar from the sentimental tradition.

One effect of this conjunction of elegiac tone, epitaphic form and photographic image for reviewing real and imaginary relationships is to complicate Armstrong's potentially reductive version of empathy. The appeal to multiple points of view marks Moss's 'Elegy' as a vehicle for representing the effect of 'open intersubjectivity' favoured in recent studies of consciousness. In Evan Thompson's view, empathy is a 'self-displacing' or 'selfothering' act.

Empathy involves a displacement or fission between my empathizing self and the empathized other; recollection between my present recollecting self and my past recollected self ... imagination between myself imagining and myself imagined ... and reflection between my reflecting self and the experiences I reflect upon. 83

Armstrong's idea that empathy is 'individualist' seems to presume a unitary, monolithic ego pitched against other such constituted egos in a 'power-ridden construction of relations' ${ }^{84}$ In their exploration of the poetics of melancholy and mourning Jones and Moss risk demonstrating that the space of the elegaic is also the space of multiple, fantastic and imaginatively projected relations. The ego, for Thompson, is structured or 
inhabited by many 'inner splittings' or 'inner openings' that 'intrinsically involve otherness' 85 Similarly, Jones and Moss suggest a poetics of displacement or fission, the effect of being 'beside oneself' as well as alongside the other.

Despite this, 'Elegy' might fail to escape entirely Armstrong's accusation. The risky aesthetic of self-othering might prove 'power-ridden' all the same. Jones self-consciously explores the thaumatrope's conjunction of black woman and white baby as a point of conduction for her nostalgic dream of (un)belonging to the black mother. At the same time, the thaumatrope's 'fast-motioning embrace' utopianly repairs the ruptures among generalised Stolen Generations. Along similar lines, but apparently without selfconsciousness, Moss's inevitably allegorical photograph provides the occasion for a fantasy projection in which the colonialist discourse of the indigene-as-child is oddly inverted. To regard unself-consiousness as a naive fault is to side with the view that selfreflexion is the necessary condition for critical effects. The poetics of self-reflexivity would repay attention on another occasion. 'Elegy' works with the inherited split between melancholy and mourning but treats them as a compositional pair, oscillating between melancholy 'photographic' stasis and the 'narrative' dynamic of mourning. Such a compositional ensemble reconvenes the dispersed elements of the empathic process but cannot undo the separation and reversal that characterise their contemporary afterlife in psychoanalytic discourse. As the dialectical model of melancholy and mourning suggests, fictocritical cross-cultural writing of this kind will struggle against the resistance of the materials with which it must work, replaying the 'neighbouring' and 'separation' of the ethical and the aesthetic. 'Elegy' is significant for its adoption of a tone and a form in which to write about the unsettling ethical imperatives of mourning, and the feelings left out of historical narratives.

\section{— Historiography, POStCOlonial ALlEgoricism AND the DiAlectic OF MOURNING}

Along with the call for postcolonial studies to honour the affects that remain as traumatic historical effects, comes the need to heal our failed readings of problematic archives. 'Who has stories to tell? What are their methodologies? How do they speak to their readers? What are the tones of their voices?'86 The therapeutic role of 'empathic witness/ analyst' falls to the cross-cultural writer who aims to provide an ethically charged, coconstituted space for postcolonial memorial aesthetics.87 To David Carter's 'ought' of the postcolonial ethics of hybridity we might now add the 'ought' of an ethics of mourning. The question that always troubles melancholy and mourning remains: can grief have a 'proper' place? Jones's assertion that an audience might find the elegiac 'intolerable'88 suggests that postcolonial elegy might be regarded as somehow troubling. Jones's 
proposal to enact an extravagant and excessive grieving, and her implication that elegy is potentially insubordinate, sit uneasily alongside literary elegy's traditional attachment to the effective management of mourning through the substitution of poetry for grief (its containment and closure of grief, its attachment to the protocols of inheritance). This should remind us that the sentimental tradition, through which these poetics of melancholy and mourning are being read, is itself invested in the management of a threatened rupture (between thought and feeling). Further, when Stern concludes that the dialectical work of mourning might 'increase the chance that traumas in representation will show themselves' as 'authentic history', in 'places that mark the incomplete healing of the wound of grief', she brings into view precisely the danger that lurks in this poetics. 89 In what amounts to a valorising of the work of the empathic imagination as the vehicle for a version of 'history as poetry' regarded with suspicion in other disciplinary contexts, history as the poetics of mourning would have to confront the perennial legacy of the sentimental tradition. The affective turn that would drive such an allegedly therapeutic discourse cannot reconvene the ethical and aesthetic spheres in the blur of a fast-motioning embrace. It can only reproduce and attempt to manage the dialectic between neighbouring but separate spheres.

The appeal to affect inevitably raises the sentimental bugbear of 'authentic feeling', if not simply in the sense implied by Coleridge's warning that 'Poetry-excites us to artificial feelings-makes us callous of real ones'. 90 Something of this question of authenticity lurks in Armstrong's view of empathy as ideological, a 'false' feeling in the service of an unethical individualism. In what might be understood as the compositional partner of this problem, the sentimental tradition is predicated on a universalist model of human 'fellow-feeling'. This assumption of innate moral sense often sneaks back in to discussion of aesthetics, ethics and empathy, with calls for moral sympathy as the preferred vehicle for a renovated humanism. These are just two of the problems that redeploying elements of sentimentalism must confront in any call for 'an ethics of writing history'. ${ }^{91}$ In conclusion it remains to suggest how fictocritical cross-cultural writing might refunction the allegoricism of colonialist historiography by recourse to the ethical imperatives of mourning. In the discourses of colonialism, allegories of history prove effective modes of cross-cultural management. 92 In the discourses of postcolonial therapeutics, especially the ethical imperative of mourning, it might appear that empathy is called upon to facilitate a refiguring of colonial allegoresis. In particular, the ethic of mourning would supplement the ethic of hybridity as method and effect of contemporary allegories of knowledge. I will suggest that this is an inevitable move when mourning and postcolonial counter-discursive allegoresis are understood to perform the same dialectical process. 
Breitwieser has suggested that the work of mourning is the 'doing of history'. ${ }^{93}$ In modelling this as a perpetual analytic reviewing of our 'wounds' in a dynamic process, rejecting static typologies and eventually letting go of grief, 'normal' mourning is represented as 'dialectic's purest case'. ${ }^{94}$ Read back through the models of empathy that characterise sentimentalist ethics, it is apparent that Breitwieser still relies on the rupture and reversal of phases of the empathic process effective in psychoanalytic theory. Despite the insight that mourning is a metaphor for dialectical praxis, Breitwieser leaves in place the pathologising of melancholy stasis, incorporation and fascinated continuity, privileging the detachment and contiguity of self and other that should conclude not make possible the empathic process. Breitwieser's investment in 'nomadic' 'perpetual motion' is at once an uncanny reverberation of an earlier romantic conception of the empathic ethical process and a perhaps strategic deployment of vocabularies available in contemporary theoretical discourses.

In his model for a remediating counter-discursive postcolonial allegoresis, Stephen Slemon maps a strikingly parallel process. Refusing the 'static', monolithic 'units of knowledge' that characterise colonial allegories of history, the postcolonial allegorist uses fictional narratives to set things moving:

Such acts of postcolonial literary resistance function counter-discursively because they 'read' the dominant colonialist discursive system as a whole in its possibilities and operations and force that discourse's synchronic or unitary account of the cultural situation towards the movement of the diachronic. 95

History as narrative fiction, like mourning, is predicated on a case-by-case and pluralising review of the archive to forestall interpretive generalisation. Reading history 'in adjacency to a fictional re-enactment of it', 'the creative and transformative exercise of reading opens a space within which new ways of formulating the past can come into being'. An effect of remediation is predicated on a space opening up, a fissuring of unity in 'heteroglossic structures' of 'dialectical reiteration'. ${ }^{96}$ This model effectively replicates the dialectic of mourning in the Freudian version preferred by Santner, Breitwieser and Stern, for example. In particular, it dispenses with the resources of allegorical figures, casting these as the equivalent of the static images deployed in the repetition compulsion of perverse melancholy fixation. Just as Santner, Breitwieser and Stern reserve empathy as a healthy effect of the 'contiguity' made possible by a process of 'grief in motion', Slemon favours the 'adjacency' of a reading practice made possible by allegory in motion. It is not entirely clear that historiography as mourning and counter-discursive allegoresis must inevitably repeat the rupture and reversal of the mechanisms that drove the machinery of empathy in the sentimental tradition. Nevertheless, fictocritical 'grief in 
motion' appears unwilling to dispense altogether with the resources of melancholy, perhaps because together melancholy and mourning reconvene valuable elements of the empathic process that characterised an earlier sentimental tradition. 97

The very name 'fictocriticism' bears the (nostalgic) history and the (utopian) promise of a dialectic in which the compositional pairs to which this discussion has drawn attention oscillate between 'neighbouring' and 'separation'. Fictocritical investments in rhetorics of mourning and counter-discursive allegoricism as 'history' cannot reinstall a Shaftesburian plenitude, fictocritical effects are nonetheless produced out of various recombinations of a fragmented and dispersed tradition in which ethics and aesthetics once belonged to the same imaginative faculty. 98 Fictocritical effects of analogical continuity produced by the (post)modernist allegorical sensibility still depend on vocabularies and concepts that attach to traditional activities of the imagination-for example, empathy and the work of mourning. While these allegories of knowledge might prove therapeutic for the discourse of postcolonial studies and its institutional audiences, it remains problematic whether or not the empathic ambition of fictocriticism can have a reparative effect for those who typically provide the occasion for writing. Even so, in the Australian context, acknowledgement of affects as important effects of history is still politically urgent. In this sense at least, fictocritical empathy and the work of mourning might be necessary, if not sufficiently radical, aesthetic gestures, keeping in view the analogical historical ties between selves and others in particular settler communities.

HEATHER KERR is senior lecturer in English at the University of Adelaide. She publishes in the areas of early modern culture, postcolonial and contemporary cultural studies.

1. Hal Foster, 'Trauma Studies and the Interdisciplinary: An Interview', in A. Coles and A. Defert (eds), The Anxiety of Interdisciplinarity, Backless Books, London, 1998, p. 160. Postcolonial studies as the equivalent of trauma studies is discussed in Heather Kerr, "The "Real Lesson of an Education in Visual Culture", Postcolonial Studies, vol. 4, 2001, pp. 91-104, at page 97.

2. Gail Jones, 'Skulls, Fontanelles and the Spaces Between: in memoriam Fanny Balbuk', The UTS Review, vol. 1, no. 2, 1995, p. 178

3. Isobel Armstrong, The Radical Aesthetic, Blackwell, Oxford, 2000, p. 234, her emphasis.

4. See, for example, Dominic Rainsford and Tim Woods (eds), Critical Ethics: Text, Theory and
Responsibility, Macmillan, Houndsmills, 1999.

5. Michael Bell, Sentimentalism, Ethics and the Culture of Feeling, Palgrave, New York, 2000, p. 29.

6. Quoting Bell on the contribution of Addison and Steele, pp. 37 and 165.

7. Bell, p.110.

8. Among others, David Hume, Adam Smith, Jeremy Bentham, Joseph Addison, William Wordsworth. James Engell, The Creative Imagination, Enlightenment to Romanticism, Harvard University Press, Cambridge, MA and London, 1981; David Marshall, The Surprising Effects of Sympathy, University of Chicago Press, Chicago, 1988; Richard Kearney, The Wake of Imagination: Toward a Postmodern Culture, Routledge, London, 1988; Rudolf Makkreel, Imagination and Interpretation in 
Kant, University of Chicago Press, Chicago, 1990; Gillian Robinson and John Rundell (eds), Rethinking Imagination: Culture and Creativity, Routledge, London and New York, 1994; Thomas McCarthy, Relationships of Sympathy, The Writer and Reader in British Romanticism, Ashgate Scolar Press, Aldershot, 1997; Julia Stern, The Plight of Feeling, Sympathy and Dissent in the Early American Novel, University of Chicago Press, Chicago and London, 1997; Heather Kerr, 'Sympathetic Topographies', Parallax, vol. 7, no. 2, 2001, pp. 107-26.

9. Bell, p. 71

10. Louise Fradenburg, "Voice Memorial": Loss and Reparation in Chaucer's Poetry', Exemplaria, vol. 2, no. 1,1990 , p. 177.

11. Marshall, p. 21

12. McCarthy notes (p. 5) the confusions between 'sympathy' and 'empathy' in the relevant literature. See also Evan Thompson, 'Empathy and Consciousness', Journal of Consciousness Studies, vol. 8, no. 5-7, 2001, pp. 1-32.

13. McCarthy, p. 8.

14. McCarthy, p. 1.

15. Engell, pp. 143-4 and McCarthy p. 3.

16. McCarthy, p. 3.

17. McCarthy, p. 8.

18. McCarthy, p. 11-12.

19. McCarthy, p. 17.

20. Gail Jones, 'Thaumatropes', in Heather Kerr and Amanda Nettelbeck (eds), The Space Between: Australian Women Writing Fictocriticism, University of Western Australia Press, Nedlands, 1998, pp. 98-114, p. 112

21. McCarthy, p. 10.

22. Jones, 'Thaumatropes', pp. 111-13.

23. Thompson, p. 19

24. Bob Hodge and Alec McHoul, 'The Politics of Text and Commentary', Textual Practice, vol. 6, no. 2, 1992, p. 205.

25. Hodge and McHoul p. 205.

26. Martin Heidegger, Being and Time (1927), trans. John Macquarrie and Edward Robinson, Blackwell, Oxford, 1962, p. 159, quoted in Armstrong p. 234 and discussed in Kerr, 'Sympathetic Topographies'.

27. William Hazlitt, The Complete Works of William Hazlitt, 21 vols, P.P. Howe (ed.), Dent, London, 1934 , vol. 5 , p. 12. See also discussion in McCarthy p. 39

28. Jones, 'Thaumatropes', p. 109.

29. Stephen Muecke, No Road (bitumen all the way), Fremantle Arts Centre Press, South Fremantle, Western Australia, 1997, p. 34. Stephen Muecke, Reading the Country: Introduction to Nomadology, Fremantle Arts Centre Press, South Fremantle, Western Australia, 1984.

30. See, for example, J.M. Bernstein, The Fate of Art: Aesthetic Alienation from Kant to Derrida and
Adorno, Blackwell, Oxford, 1992; Max Pensky, Melancholy Dialectics: Walter Benjamin and the Play of Mourning, University of Massachusetts Press, Amherst, MA, 1993.

31. Peter Burger, Theory of the Avant-Garde, University of Minnesota Press, Minneapolis, 1984, pp. 69, 70.

32. Eric Santner, Stranded Objects: Mourning, Memory and Film in Postwar Germany, Cornell University Press, Ithaca and London, 1990, p. 12.

33. Quoted in Susan Buck-Morss, The Dialectics of Seeing: Walter Benjamin and the Arcades Project, MIT Press, Cambridge, MA, 1989, p. 165.

34. Linda Nochlin, The Body in Pieces: The Fragment as a Metaphor of Modernity, Thames and Hudson, London, 1994, pp. 24, 25.

35. Burger, p. 69

36. Gregory Ulmer, 'The Heuretics of Deconstruction', in P. Brunette and D. Wills (eds), Deconstruction and the Visual Arts: Art, Media, Architecture, Cambridge University Press, Cambridge, 1994, p. 96.

37. Steven Connor, 'The Ethics of the Voice', Rainsford and Woods, pp. 220-37. Ghosts: Klaus Neumann, 'Remembering Victims and Perpetrators', The UTS Review, vol. 4, no. 1, 1998, p. 8.

38. James Clifford, 'On Ethnographic Allegory', in James Clifford and George Marcus (eds), Writing Culture: The Poetics and Politics of Ethnography, University of California Press, Berkeley, California, 1986, p. 99.

39. Ulmer, pp. 83,90

40. Clifford, p. 100.

41. Ricoeur, p. 126, Stephen Muecke, 'Body, Inscription, Epistemology: Knowing Aboriginal Texts' in Textual Spaces: Aboriginality and Cultural Studies, New South Wales University Press, Sydney, 1992, pp. 36-59.

42. Kearney, p. 366.

43. See, for example, Steven Connor, 'Ethics of Voice' and 'Renunciation and Sublimity: On Critical Modesty', in Postmodern Culture: An Introduction to Theories of the Contemporary, Blackwell, Oxford, 1989 , pp. 201-223.

44. Gaye Tuchman, 'Historical Social Science: Methodologies, Methods, and Meanings', in N.K. Denzin and Y.S. Lincoln (eds), Handbook of Qualitative Research, Sage, London, 1994, p. 317.

45. Stephen Greenblatt, Allegory and Representation, Johns Hopkins University Press, Baltimore 1981, p. viii.

46. Jones, 'Skulls, Fontanelles and the Spaces Between', p. 171.

47. Jones, 'Skulls, Fontanelles and the Spaces Between', p. 179.

48. Hodge and McHoul, p. 189.

49. Paul Carter, The Road to Botany Bay: An Essay in Spatial History, Faber and Faber, London, 1987, p. 348. 
50. Carter, The Road to Botany Bay, p. 348, his emphasis.

51. Carter, The Road to Botany Bay, p. xxii.

52. Ken Gelder and Jane M. Jacobs, 'Uncanny Australia', The UTS Review, vol. 1, 1995, p. 156. Also Uncanny Australia: Sacredness and Identity in a Postcolonial Nation, Melbourne University Press, Melbourne, 1998

53. Paul Carter, The Lie of the Land, Faber and Faber, London, 1996, p. 5.

54. McCarthy, pp. 1, 11.

55. Derrida, Barthes, Lyotard and De Certeau each take the function of mourning as the contemporary condition of writing. For mourning as a cultural analytic: Bernstein, Pensky, Santner, Stern Plight of Feeling. Also Mitchell Breitwieser, American Puritanism and the Defense of Mourning: Religion, Grief, and Ethnology in Mary White Rowlandson's Captivity Narrative, University of Wisconsin Press, Madison, WI, 1990; Julia Stern, 'To Represent Afflicted Time: Mourning as Historiography', American Literary History, vol. 5, 1993, pp. 37888; Martin Jay, 'The Apocalyptic Imagination and the Inability to Mourn', in Robinson and Rundell, pp. 30-47.

56. Sigmund Freud, 'Mourning and Melancholia', in Peter Gay (ed.) The Freud Reader, Vintage, London, 1995 , pp. 584-9. On 'the fort/da game' as a symbolic management of grief see Sigmund Freud, 'Beyond the Pleasure Principle', in Gay, pp. 594626. This 'mourning play' is discussed in Catherine Bates, Play in a Godless World; The Theory and Practice of Play in Shakespeare, Nietzsche and Freud, Open Gate Press, London, 1999, pp. 170218. Santner, p. 20, on the fort/da game as 'elegiac procedure'. Play is an important fictocritical effect that I do not have space to consider here.

57. Santner, p. 3.

58. Santner, p. 6.

59. Santner, p. 7.

60. Breitwieser, Jay, Santner, Stern in both 'To Represent Afflicted Time' and Plight of Feeling, view 'obstructed mourning' as culturally dominant at particular historical junctures.

61. Breitwieser, p. 206. Compare Stern, 'To Represent Afflicted Time', p. 383.

62. Stern, p. 383.

63. Santner, p. 7.

64. Santner, p. 29.

65. Ricoeur, p. 130.

66. Jones, 'Thaumatropes', p. 111.
67. Santner, p. 29.

68. Jones, 'Skulls, Fontanelles and the Spaces Between', p. 179.

69. Armstrong, p. 234.

70. Stern, pp. 383, 386 and 387.

71. Santner, pp. 7, 8.

72. Jones, 'Skulls, Fontanelles and the Spaces Between', pp. 178, 179.

73. Ulmer, 'Heuretics', pp. 94, 95.

74. Fradenburg, p. 177.

75. Fradenburg, p. 183, quoting from Freud's letter in which melancholy and mourning are not so rigidly polarised.

76. Jones, 'Thaumatropes', p. 112

77. Nochlin, p. 53.

78. Rob Moss, 'Elegy', The UTS Review, vol. 3, no. 2 1997, pp. 142-48.

79. Jones, 'Skulls, Fontanelles and the Spaces Between', p. 197.

80. Moss, pp. 148, 142.

81. Moss, p. 148

82. Jones, 'Thaumatropes', p. 102.

83. Thompson, p. 20.

84. Armstrong, p. 234

85. Thompson, p. 20.

86. B. Kruger and P. Mariani (eds), Re-Making History, Bay Press, Seattle, 1989, pp. ix, x.

87. Santner, p. 25.

88. Jones, 'Skulls, Fontanelles and the Spaces Between', p. 127.

89. Stern, p. 386

90. Geoffrey Hill, The Lords of Limit, Andre Deutsch, London, 1984, pp. 3, 4.

91. Klaus Neumann, 'Cropped Images', Humanities Research, vol. 1, 1998b, p. 41.

92. Stephen Slemon, 'Monuments of Empire: Allegory/ Counter-Discourse/Post-Colonial Writing', Kunapipi, vol. 9, no. 3, 1987, p. 6. See also Bill Ashcroft, 'Allegory', in Post-Colonial Transformation, Routledge, London and New York, 2001, pp. 10423.

93. Breitwieser, p. 4.

94. Breitwieser, p. 42.

95. Slemon, p. 13.

96. Slemon, pp. 12, 13.

97. Anna Gibbs's work is a richly productive fictocritical deployment of 'melancholic sensibility' and an empathic textual attention to love and suffering. See, for example, 'The Gift' and 'Afterword' in Kerr and Nettelbeck, pp. 31-52. 98. Bell, p. 31. 